\title{
The Reality of the Meetings of the Academic Councils at Naif Arab University for Security Sciences and its obstacles
}

\author{
Dr. Husain K.M. Abed Alqader \\ Alistiqlal University, Palestine
}

\begin{abstract}
The study aimed to identify the reality of following the modern methods in the meetings of the academic councils in Naif Arab University for Security Sciences and its obstacles. The number of the study society reached 102 members of the academic councils in the university. The researcher used the method of the comprehensive sample and using the descriptive method, On the ground, the questionnaire was used to identify the views of the study community on the answer to the three axes of the study, using the Statistical Package Program (SPSS) for analysis and statistical processing. The study reached many conclusions, including: The objectives of the meeting are determined accurately, and the place and time of the meeting are determined in the invitation, and emergency meetings are called when necessary. Delegations are delegated to members, and decisions are taken after consultation with the experts at the meeting. The meeting is concluded on time and to a medium extent of the responses of the study community. Lack of incentives for active members. And the results of the meeting do not send a written letter to the participants, the results of the study showed that the overlap between administrative and academic practices and individual decision-making, the absence of material and moral incentives for members and the lack of a specific time for the end of the meeting are one of the most important difficulties facing the management of meetings. The study reached several recommendations, including: the need to delegate powers to members participating in meetings. Decisions must be made after consultation with the meeting specialists. The need to end the meeting in time for him to stay away from the waste of time. Physical and moral incentives should be provided to the active members of the meetings as they have a significant impact on increased attention and activity in the implementation of the decisions of the meetings.
\end{abstract}

Keywords : Meetings, Academic Councils, Security Sciences

DOI: $10.7176 / \mathrm{EJBM} / 12-3-07$

Publication date: January $31^{\text {st }} 2020$

\section{Introduction}

The subject of the management of meetings is a modern subject in the science of management on the grounds that the human needs in all aspects of life, whether meetings on a social level or at the level of work within organizations and institutions of different forms, and the most important meetings here in the field of the work of institutions, including educational and academic, Since it is impossible to imagine the existence of a public or private organization or institution without holding meetings within or outside of its staff and leaders, where meetings became a practical scientific necessity for the success of institutions.

Since higher education institutions are the mainstays in which science develops, knowledge is discovered, and skills are developed, most institutions of higher education have made progress in planning strategies that support the growth and development of education and scientific research. The improvement of their performance and the overall quality of their systems, processes and outputs have shown interest Based on the contributions of the leaders of the administration, and the pursuit of spreading the culture of excellence to the continuous improvement in the formulation and identification of indicators according to the modern science of development and uplift. (Dajni, 2011, p. 5)

The researcher believes that the meetings in the educational institutions have their own status, considering that the educational academic work is mostly achieved only through the meetings, both in the boards of academic departments or colleges, and therefore the good planning and the orderly preparation of the meeting contribute significantly to the success and achievement of its objectives, From this point of view, the idea of the study came to try to identify the reality of the meetings of the academic councils at Naif Arab University for Security Sciences and its obstacles from the point of view of its members and in terms of planning and good preparation and organization for the management of meetings. Rh meetings and knowledge of constraints and ways to improve the efficiency and performance so as to achieve the objectives of the educational process at the university, good investment for times of meetings.

\subsection{The problem of the study:}

The management of meetings is one of the important topics that senior management in the universities attach to the importance of whether it is before, during or after the meeting, and to know the effectiveness of administrative meetings and the practical benefit of managing them properly and successfully. This concern comes to the management of meetings due to problems and errors that occurred in them Many administrations have been 
ignorant of the good and effective preparation of their activities, and consequently the failure to achieve their goals, especially since most managers spend long periods in the meetings and preparation for them. Some studies have indicated that $50 \%-70 \%$ of the time managers spend Tariq (Al-Munif, 2004, 4).

In the opinion of the researcher that the academic councils rely in most universities in their decisions on the conclusions and recommendations reached by the academic meetings, which means that these meetings of great importance in the adoption of appropriate and effective decisions, if the meetings failed in their discussions and recommendations, it has a negative impact on performance In addition to its ability to achieve its educational and academic goals and future plans. This in turn stimulates the management of academic institutions to give great importance to meetings as a means of accomplishing tasks and achieving goals. And the guidance that serves all students and staff of the university, so the effectiveness of decisions and guidance that emanates from the meetings and their implications reflect how the management of these meetings from the planning, implementation and organization of these meetings and raise the efficiency of its performance.

In addition to the above, the problem of the study centered on answering the following main question:

"What is the reality of the meetings of the academic councils at Naif Arab University for Security Sciences and its obstacles?"

\subsection{Study Questions:}

1. What is the reality of modern methods in the meetings of the academic councils at Naif Arab University for Security Sciences from the point of view of its members?

2. What are the obstacles that limit the efficiency of the performance of the meetings of the academic councils at Naif Arab University for Security Sciences from the point of view of its members?

\subsection{The study hypothesis:}

There were no statistically significant differences in respondents' opinions on the study's axes due to the variables of personal and functional study.

\subsection{Objectives of the study:}

1. Identify the reality of modern methods in the meetings of the academic councils at Naif Arab University for Security Sciences from the point of view of its members?

2. Identify the main obstacles that limit the efficiency of the performance of the meetings of academic councils at Naif Arab University for Security Sciences from the point of view of its members?

3. Determine whether there are statistically significant differences between the reality of the meetings of the academic councils at Naif Arab University for Security Sciences and its constraints due to the variables of personal and functional study.

\subsection{The Importance of the Study:}

The importance of the study stems from the importance of its subject, which is one of the few studies that dealt with the management of academic councils in Arab universities, and this is considered sufficient justification for the importance of this study. This study is of practical benefit to the faculty, which implements and implements the decisions and recommendations of the meetings of the academic councils of the university. It also contributes to providing a degree of factual information and data on the administrative and academic functions of the academic boards of the universities. The study helps the management of universities in determining the tasks and administrative roles of the academic councils in the universities and expected to exercise to raise the efficiency of the educational process and the development of administrative work in universities.

\subsection{The limits of the Study:}

The Human Limit: All members of academic councils at Naif Arab University for Security Sciences.

Place Limit: Naif Arab University for Security Sciences, Riyadh, Saudi Arabia.

Temporal Limit: The study was conducted during the second semester of 2018.

\section{Theoretical framework}

A meeting is a meeting of a group of people or staff at a specific time and place to discuss a topic or agenda in order to achieve the goals and objectives of the meeting. The meeting is a means of reaching the goals and not an end in itself. Meetings are an integral part of human life, and there is no working environment in any organization without effective meetings where objectives are achieved.

\subsection{Concept meetings:}

Marlene $(2010,11)$ defined the meeting as "gathering two or more persons at a specific time and place to participate in the exchange of information, ideas, opinions, planning activities, and making decisions according to an agenda 
known to participants and defined in advance." The meetings were defined as "a meeting between two or more persons in one place and at a specific time at different levels. The purpose of the meeting is to consult, discuss and discuss specific issues of understanding and agreement" (Al-Sakarna, 2009, 427). The meeting was also defined as "a meeting between a group of individuals belonging to one regulatory body, who gather together to exchange ideas and information on a particular subject and make the necessary decisions thereon." (Maher, 2000, 162).

The researcher defined the meetings as "an administrative skill that involves the gathering of two or more persons in a particular place and time to deliberate on a problem or a particular topic during which ideas and information are exchanged to reach agreement or decision by consensus or majority on that problem, taking into account the public interest and laws and regulations efficiently and effectively.

2.2 Elements of the meeting: Select (Ameri, 2007, 10) the elements of the meeting as follows:

1. Two or more people have a goal to pursue.

2. There is interaction between the participants in the meeting.

3. The existence of regulations and laws that govern the meetings, whether written or not

4. The presence of commitment by the persons at the place and time of the meeting.

\subsection{The importance of meetings:}

Meetings are one of the most important means of communication and their vital role as an important activity in management at the level of individuals and organizations. (Al-Sakarna, 2009, 429) pointed out that meetings can achieve the following:

1. To achieve full, comprehensive, thorough and careful studies of decisions on large topics through the diversity of members' experiences and their constructive discussions based on advice and exchange of views

2. reaching collective decisions characterized by maturity, depth, honesty and objectivity contrary to individual decisions that depend on personal abilities and sometimes characterized by bias and personal interests.

3. Coordination between different aspects of activities and efforts between departments and departments within a single organization or with other organizations.

4. Provide the opportunity for experienced staff to contact those who are older than experience, practice and experience.

5. Provide the opportunity for the administrative leaders and participants in the meeting to communicate their views, directions and views to the rest of the staff through the participating members, while at the same time providing the demands and complaints of employees.

6. Raise the morale of participating members by giving them the opportunity to express their opinions and ideas and participate in decision-making.

2.4 Reasons for convening a meeting: Anderson $(2012,7)$ noted five main reasons for convening a meeting:

1. To provide the participants with information on a subject that can only be provided through a meeting.

2. Obtain information from the participants about a particular subject.

3. Develop options: hear the views and perceptions of participants in the meeting to create an idea or plan for a specific subject before the study.

4. Make a decision regarding the future planning of the institution.

5. If the President of the Foundation requests a meeting.

2.5 Reasons for not convening a meeting: (Gary, 2012, 115) noted six reasons why a meeting should not be held: 1. The need to reformulate the agenda items or the absence of a key member of the meeting.

2. If the agenda is not distributed to the claimants well in advance of the date of the meeting.

3 . If the purpose of the meeting is unclear and show it as a way to waste time.

4. If it is found that the purpose of the meeting can be achieved using other means such as e-mail or telephone.

5. Lack of the necessary equipment for holding the meeting such as the appropriate place and electronic equipment.

6 . Removal of the purpose and purpose of the meeting prior to the date of the meeting.

2.6 Meeting types: There are many types of meetings, but the type of meeting appropriate to the purpose or purpose of the meeting and the conditions for the meeting must be chosen. Boehme, 2010, 4 mentioned a number of meeting types:

1. Leadership meeting: includes the head and leadership members of the institution.

2. The meeting of the management of the institution: be to solve a problem or because of a variety of reasons for convening a meeting, such as changing the policy of the institution or improve performance.

3. Annual Meeting: The meeting is held once a year and all members of the Foundation participate, such 
as approving the administrative and financial report or approving the strategic plans.

4. Meetings of seminars: aims to provide the participants with data, information and decision-making, and be interactive with the audience and take opinions and ideas.

5. Workshop meetings: It is usually a training meeting for participants to develop their skills or provide them with information about the work.

6. Conference Meeting: It aims to discuss, consult and exchange information among the participants, and in the form of sessions of groups of participants to reach conclusions and recommendations for topics on the table.

7. Meeting of agreements: to discuss a specific issue and reach agreement on it.

8. Preparatory meeting: aims to encourage and motivate employees to improve performance.

\subsection{Planning of Meetings}

In order to obtain positive results and increase the productivity of the meeting, it is necessary to plan well before inviting the meeting, as poorly planned meetings lead to loss of time for staff and institution together. Gaines (2011,

15) noted several important steps to consider to hold a meeting that includes the following:

1. The purpose and purpose of the meeting shall be clear and written in the agenda.

2. Knowing who are the persons involved in the attendance of the meeting whose views are important to meeting the objectives of the meeting. The number of participants can be limited by the use of additional means of information sharing, such as choosing the right person who can communicate information to other employees in his / her constituency.

3. Adoption of the time required for the meeting and its distribution to the agenda items.

4. Information about the meeting and its place, date and time of the invitees in advance and can be used e-mail for this and in sufficient time.

5. Prepare a clear agenda that includes: a clear date, venue and equipment, a clear summary of the meeting's objective and the topics to be discussed distributed over the meeting time.

6. Select the appropriate time and staff time.

7. Distribute the agenda and any other data and attachments to the claimants before the meeting in a timely manner so that the plaintiffs can prepare themselves for the meeting.

8. Ensure that meeting supplies and assistive aids are available at the meeting venue.

9. Send an additional reminder to the meeting attendees.

\subsection{Academic Departments at the University}

Select (Harbi, 2001, 50) Academic Departments at the University to the following:

1. The academic departments according to the university branches: These are the departments that exist in some colleges such as literature (languages, history, geography, philosophy), and some sections of the Faculty of Science, those sections and branches of knowledge that constitute the education program in the college and distinguish them from professional or technical studies.

2. Academic departments in vocational colleges: They prepare students for a specific occupation such as medicine, engineering and agriculture.

3. Academic departments in educational centers and institutes with specific programs: They are characterized by technical aspects and applied research.

\subsection{Duties of heads of academic departments}

The head of the department supervises the scientific, administrative and financial affairs of the department within the limits of the policy determined by the college council and the department council in accordance with the provisions of the laws and decisions in force, in particular, he shall undertake the following: (Al-Hawali, 2005, 18) 1. Prepare the distribution of lectures, lessons and other university work to the faculty members who teach in the department.

2. Preparation of proposals for training for training outside the college to be presented to the department council.

3. Proposing the graduate and research plan in the department.

4. Follow up the implementation of decisions and policy of the Council of the Department and the College.

5. Supervise the employees in the department and monitor their work.

6. Save the system within the partition.

In addition, Warren and Geoffrey set several roles for the head of the university's academic department: providing the members of the department with a variety of information, communicating the department's activities and news quickly to the dean, clarifying the university's mission and objectives to the faculty members and careful planning. Collaborating with all, self-reliance in making difficult decisions, and cooperating with colleagues in making other decisions. (Sadeh, 2003, 3) 


\subsection{Previous studies}

Study (Alhajili, 2010). Entitled "The views of the heads of academic departments at the University of Dhamar towards their administrative and academic duties", The study aimed to identify the opinions of the heads of the academic departments at the University of Dhamar towards their administrative tasks and to determine the extent to which there is a difference in those opinions can be attributed to the impact of the two variables of experience in the head of the department and the type of specialization of the college, the researcher used the descriptive descriptive method through the design of a questionnaire, That the administrative sub-tasks are important to recognize the heads of academic departments in achieving the objectives of their departments, and that there are deficiencies in the areas of training and professional growth and communication tasks and the development of mutual relations.

Study (Masri, 2007). Entitled "Development of the administrative performance of the heads of academic departments in Palestinian universities in light of the principles of TQM", The study aimed to identify the level of administrative performance of the heads of the academic departments in the Palestinian universities in the light of the principles of TQM from the point of view of the lecturers and to identify obstacles to the application of the heads of the academic departments of the principles of total quality during their administrative work. The researcher used the descriptive analytical approach to achieve the objectives of the study, : The first to measure the level of administrative performance of the heads of academic departments, and the second to reveal the obstacles applied by the heads of academic departments of the principles of TQM during their administrative work, and the study found that the level of administrative performance of Worsened academic departments in the Palestinian universities and decision-making on the basis of medium facts, and that there is an acceptable degree of obstacles they face when applying the principles of total quality, including the achievement of user satisfaction and constraints of strategic planning and continuous improvement and excellence, and obstacles to effective leadership.

Study (Ameri, 2007). Entitled "Effectiveness of the management of meetings in the councils of the academic departments at King Saud University", the study aimed to identify the good preparation of meetings and the scheduling of meetings and their effectiveness in the councils of academic departments at King Saud University. The researcher used the descriptive method in his methods of survey and analytical to explore the reality of the phenomenon studied and to achieve the objectives of the study and answer to The most important of which was that the dates of the meetings were determined in an appropriate and timely manner and that they did not set a date for the next meeting. Most of the members of the sample agreed that the agenda items were designed to achieve the objectives of the meeting And that there is no active participation of members in the subcommittees, the lack of a comfortable environment and the necessary equipment for the meeting room, and that the presence of important members of the meeting has a negative impact on the meeting.

A study (Barhoum, 2006). Entitled "The reality of the management of the meetings of the academic departments in the Palestinian universities from the perspective of faculty members and ways of activating them." The study aimed to identify the reality of the management of the meetings of the academic departments in the Palestinian universities and ways of activating them. The researcher used the analytical descriptive method by designing a questionnaire as a study tool related to the management of meetings. The study found that the heads of the departments in the Gaza universities for their role in the management of the meetings were good and that the main problems facing them are not to benefit from the feedback in the Modifying the plans and behavior of the employees and not giving the side of scientific research enough importance among the topics on the agenda, and not to use the members of the faculty when the agenda.

Study (Alonzo, 2004). Entitled "Evaluation of Meetings", the study reached several conclusions, including: the meeting is essential to improve the quality and effectiveness of the meeting, and that eight important practices in building the evaluation strategy are the following: Development of the organizational plan before the start of the meeting, building measurable goals, Identify what should be done with its implementation dates, establish specific criteria for achieving objectives, identify data sources, design appropriate methodology to answer evaluation questions, develop an evaluation project plan and use results to improve future meetings.

Study (Shoaib, Abdel Rahman, 2004). The aim of the study was to evaluate the performance of the heads of departments before, during and after the meeting and the skill of managing the meeting. The researcher used the analytical descriptive method based on the questionnaire to collect information about the head of the department. The results of the most important: Evaluation of the faculty members of the heads of departments and college councils is positive, and that there are scientific foundations for the selection of the head of department and deans, and that the minutes of meetings to the senior management, and allows the members of the College Council to see the minutes of the meeting.

Study (Al-Hawamdeh,2003). The study used a descriptive field approach to data collection. The study concluded that there is a relationship between the elements of planning meetings and their implementation. And follow-up with the variable adequacy of meetings, and that the setting of goals and the selection of participants as dimensions of planning, received $(56.9 \%)$ of the variance in the adequacy of meetings. 
Study (Messmar, 2002). Entitled "The effectiveness of meetings in organizations", the study found that the ineffectiveness of meetings cost organizations a lot of time and money, and that managers spend about eight hours each week in unnecessary meetings. It is recommended to increase the effectiveness of the meeting by: making sure that the meeting is needed, the meeting venue suitable for its purposes, the right choice for the participating members, the existence of an agenda, following the agenda as planned, encouraging open discussion, focusing on the topic of discussion and taking notes. With each other and listen to the opinions of others.

Study (kara, 2001). The purpose of the study was to find out the necessary foundations for holding meetings. It reached several conclusions, including: determining the need for the meeting and whether the problem can be solved without a meeting and that the agenda should be sent in sufficient time to make the participants more willing, Making them more focused, adhering to the agenda, discussing topics one by one, urging attendees to participate, summarize the results, send them to all participants, and define their responsibilities and commitment.

\subsection{Comment on previous studies:}

The field studies that dealt with the subject of the study are few, although the management of meetings is the essence of modern management and the basis of the universities in making their academic decisions, and through research in administrative literature has been monitoring the previous studies, which dealt in some parts management meetings, There is a shortage in the fields of training and professional growth and communication tasks and the development of mutual relations, while the study of the (Masri, 2007) that the level of administrative performance of heads of academic departments in Palestinian universities and decision-making on the basis of facts, Al-Amiri pointed to the lack of active participation of members in the sub-committees and the lack of a comfortable environment and the necessary equipment for the meeting room. While the Alonzo study found that the meeting is essential to improve the quality and effectiveness of the meeting. The Barhoum study concluded that the feedback is not used to modify the plans and behavior of the employees and not to give the side of scientific research sufficient importance, and this is consistent with this study. The Hawamah study concluded that there is a relationship between the elements of meeting planning, implementation and follow-up with the meeting adequacy variable. The Messmar study found that the ineffectiveness of the meetings cost the organizations a lot of time and money, and managers spend about eight hours each week in unnecessary meetings. The Kara study concluded that the results should be summarized and sent to all participants and their responsibilities and commitment identified. This result was similar to the current research results.

Although the current study has benefited from previous studies and has been similar to each other in dealing with the stages of the meetings and their concept, it has been distinguished in its exposure to how to plan the management of meetings in three stages and from the point of view of academics at Naif Arab University, as this university combines two methods of education : The academic and security, and this study was distinguished from other studies that it was interested in studying the reality of the management of meetings in a security university to clarify the effectiveness of the management of these meetings, and know the pros and cons and the development of recommendations and proposals to promote the pros and cons Reducing the negatives, and activating the management of meetings in the university to achieve its objectives.

\section{Method and procedures}

\subsection{Methodology Of The Study:}

The analytical descriptive approach was used to obtain the study data, This approach is important in describing the phenomenon of study And for the purpose of dealing with facts,,the data collection method was used to survey the views of the study community and to identify it to answer the questions of the study and to survey their views on the "reality of the meetings of the academic councils at Naif Arab University for Security Sciences and its obstacles".

\subsection{Population and Sample:}

The study population is composed of all faculty members of the 102 faculties of the Naif Arab University for Security Sciences. The overall sample method was used in view of the number of such studies and their accessibility to all of them.

\subsection{Data collection tools:}

The researcher designed the questionnaire, distributed to the members of the study community, And the academic component of the Naif Arab University for Security Sciences on the subject of "the reality of the meetings of the academic councils in the Naif Arab University for Security Sciences and Constraints" has been distributed (102) questionnaire retrieved (75) questionnaire, or $74 \%$, which is suitable for generalizing the results, The reason for not collecting all the questionnaires is that the study was conducted at the end of the second semester of the academic year 2017/2018, and part of the faculty went to the summer vacation. The questionnaire consisted of two parts as follows: 
- Section I: personal and functional data, consisting of (6) paragraphs.

- Section II: axes of the questionnaire, which consists of two axes are shown as follows:

The first axis: the reality of modern methods in the meetings of the academic councils at Naif Arab University for Security Sciences from the point of view of its members, which consists of (34) paragraph.

Second: Constraints that limit the efficiency of the performance of the meetings of the academic councils at Naif Arab University for Security Sciences from the point of view of its members, which consists of (21) paragraph.

\subsection{Measure the validity and stability of the questionnaire:}

In order to measure the accuracy of the questionnaire, it was presented to a number of arbitrators and academics with expertise and expertise who are familiar with the subject of the study. They examined, corrected, reviewed and reviewed the researcher's opinions. The reliability of the test was measured by the Kronbach alpha equation, which refers to the structural truth, or the so-called homogenization. The total stability value of the identification axes was found to be 0.84 .

Table 1

Results of the Kronbach alpha coefficient for stability of the study instrument (total stability)

\begin{tabular}{|c|c|c|c|c|}
\hline $\begin{array}{l}\text { Alfa } \\
\text { Value }\end{array}$ & $\begin{array}{l}\text { Number Of } \\
\text { Paragraphs }\end{array}$ & $\begin{array}{c}\text { Number Of } \\
\text { Cases }\end{array}$ & Level & Section \\
\hline 0.95 & 34 & 75 & $\begin{array}{c}\text { Overall Consistency Of The } \\
\text { Questionnaire }\end{array}$ & first \\
\hline 0.72 & 21 & 75 & $\begin{array}{c}\text { Overall Consistency Of The } \\
\text { Questionnaire }\end{array}$ & Second \\
\hline 0.84 & 55 & 75 & \multicolumn{2}{|c|}{ Total stability of the axes of the questionnaire } \\
\hline
\end{tabular}

The higher the alpha value, the more stable the resolution would be in giving good results to analyze the subject of the study. It was agreed that the value of 0.6 and above is an acceptable value for the stability of the questionnaire (Malhotra, 2007, p62).

From the result obtained, the value of alpha is excellent, indicating the stability of the questionnaire and indicating the formative truth of the questionnaire or the so-called homogeneity of the resolution paragraphs.

\subsection{Statistical processing:}

After the collection of the study data, the researcher reviewed it in preparation for its introduction into the computer. This was done by giving specific numbers, ie, by converting the verbal answers to the other numerical ones. All the study questions were selected and analyzed using the statistical program (SPSS) Arithmetical averages and standard deviations.

\subsection{View the results of the study:}

The weighted average of the responses of the members of the study population was calculated on the study axes using the five-dimensional Likert scale in order to know the direction of the respondents' opinions and the various comparisons. The Likert scale is considered the best method for measuring trends.

(2)Table

\begin{tabular}{|c|c|c|c|c|c|}
\hline Strongly Agree & Agree & neutral & Disagree & Strongly Disagree & Response \\
\hline 5 & 4 & 3 & 2 & 1 & Degree \\
\hline $5-4.2$ & $4.19-3.4$ & $3.39-2.6$ & $2.59-1.8$ & $1.79-1$ & Arithmetic mean \\
\hline Very large & large & Medium & weak & Very weak & Level \\
\hline
\end{tabular}


3.7 Description of the Study Community: The following table shows the level, number and percentages of the study population.

Table (3)

Number and percentages of members of the study community by study variables

\begin{tabular}{|c|c|c|c|}
\hline Percentage $\%$ & Frequencies & Level & Variable \\
\hline 37.3 & 28 & Assistant Professor & \multirow{3}{*}{ Academic level } \\
\hline 41.3 & 31 & Associate Professor & \\
\hline 21.4 & 16 & professor & \\
\hline 9.3 & 7 & Less Than 5 Years & \multirow{4}{*}{ Years of Experience } \\
\hline 24.1 & 18 & 5 - Less Than 10 Years & \\
\hline 13.3 & 10 & 10 -Less than 15 years & \\
\hline 53.3 & 40 & years and over 15 & \\
\hline 5.3 & 4 & Less than 30 years & \multirow{4}{*}{ Age } \\
\hline 21.3 & 16 & From 30 to less than 45 years & \\
\hline 40.1 & 30 & From 45 years to less than 60 years & \\
\hline 33.3 & 25 & years and over 60 & \\
\hline 22.7 & 17 & administration science & \multirow{6}{*}{ College } \\
\hline 26.7 & 20 & Social Sciences & \\
\hline 20.0 & 15 & Strategic Science & \\
\hline 13.3 & 10 & Criminal justice & \\
\hline 4.0 & 3 & Criminal Evidence & \\
\hline 13.3 & 10 & Computer & \\
\hline 70.7 & 53 & The section & \multirow{3}{*}{$\begin{array}{l}\text { Meetings in which they } \\
\text { participate }\end{array}$} \\
\hline 8.0 & 6 & College & \\
\hline 21.3 & 16 & Both are together & \\
\hline 53.3 & 40 & Yes & \multirow{2}{*}{$\begin{array}{l}\text { Have you got a training } \\
\text { course in meeting } \\
\text { management? }\end{array}$} \\
\hline 46.7 & 35 & No & \\
\hline
\end{tabular}

3.8 Answering the questions of the study and discussion:

To answer the study questions in this section the researcher displays the results of respondents' answers on the questionnaire and items are analyzed and discussed in the following table:

The first axis: the reality of modern methods in the meetings of scientific councils at Naif Arab University for Security Sciences from the point of view of its members. 
Table (4)

The attitudes of the members of the study community on the first axis

\begin{tabular}{|c|c|c|c|c|c|c|c|c|c|}
\hline \multicolumn{10}{|c|}{ Theme 1: Preparation and preparation of meetings prior to the meeting } \\
\hline Level & $\begin{array}{l}\text { Standard } \\
\text { Deviation }\end{array}$ & $\begin{array}{l}\text { Arithmetic } \\
\text { Mean }\end{array}$ & $\begin{array}{l}\text { Strongly } \\
\text { Disagree } \\
(\%)\end{array}$ & $\begin{array}{c}\text { Disagree } \\
(\%)\end{array}$ & $\begin{array}{c}\text { Neutral } \\
(\%)\end{array}$ & $\begin{array}{c}\text { Agree } \\
(\%)\end{array}$ & $\begin{array}{c}\text { Strongly } \\
\text { Agree } \\
(\%)\end{array}$ & Paragraph & No. \\
\hline Large & 1.14 & 3.56 & 8 & 14.7 & 4 & 60 & 13.3 & $\begin{array}{l}\text { The views of the } \\
\text { members shall be } \\
\text { taken into account } \\
\text { in preparing for the } \\
\text { meeting }\end{array}$ & 1 \\
\hline Large & 1.09 & 3.77 & 8 & 5.3 & 8 & 58.7 & 20 & $\begin{array}{l}\text { The objectives of } \\
\text { the meeting are } \\
\text { precisely defined. }\end{array}$ & 2 \\
\hline Large & 0.78 & 4.15 & 4 & 0 & 0 & 69.3 & 26.7 & $\begin{array}{l}\text { Specifies the place } \\
\text { and time of the } \\
\text { meeting in the } \\
\text { invitation }\end{array}$ & 3 \\
\hline Large & 1.17 & 3.63 & 8 & 9.3 & 17.3 & 42.7 & 22.7 & $\begin{array}{l}\text { The agenda of an } \\
\text { annex shall be } \\
\text { circulated by } \\
\text { invitation to the } \\
\text { meeting. }\end{array}$ & 4 \\
\hline Large & 1.22 & 3.49 & 4 & 25.3 & 12 & 34.7 & 24 & $\begin{array}{l}\text { The invitation to } \\
\text { the meeting shall } \\
\text { be sent well in } \\
\text { advance. }\end{array}$ & 5 \\
\hline Large & 1.10 & 3.69 & 4 & 13.3 & 16 & 42.7 & 24 & $\begin{array}{l}\text { Arrange seating } \\
\text { sites appropriately. }\end{array}$ & 6 \\
\hline Large & 1.06 & 3.64 & 4 & 13.3 & 16 & 48 & 18.7 & $\begin{array}{l}\text { The meeting place } \\
\text { is initialized ahead } \\
\text { of schedule. }\end{array}$ & 7 \\
\hline Large & 0.79 & 4.17 & 4 & 0 & 0 & 66.7 & 29.3 & $\begin{array}{l}\text { Emergency } \\
\text { meetings are called } \\
\text { when necessary }\end{array}$ & 8 \\
\hline Large & 1.04 & 3.76 & & & & Tot & & & \\
\hline
\end{tabular}

Table (4) shows that the total score for all the first axis averages was (3.76) and by a standard deviation of (1.04). This indicates a high degree of approval among the surveyors on this axis , And paragraph (8), which states that "emergency meetings are called when necessary" at the top of the mean (4.17), with a standard deviation of (0.79) indicating a high degree of approval. Which states that "the place and time of the meeting shall be determined in the invitation" with a mean (4.15) and with a standard deviation of $(0.78)$ which is a great degree of approval, and The third place came paragraph (2) "defined the objectives of the meeting accurately" mean (3.77) and standard deviation (1.09), a large degree of approval. These results demonstrate the extent to which the university is interested in managing meetings as important for academic decision making. 
(5)Table

The attitudes of members of the study community on the first axis

\begin{tabular}{|c|c|c|c|c|c|c|c|c|c|}
\hline Level & $\begin{array}{c}\text { Standard } \\
\text { Deviation }\end{array}$ & $\begin{array}{l}\text { Arithm } \\
\text { etic } \\
\text { Mean }\end{array}$ & $\begin{array}{c}\text { Strongly } \\
\text { Disagree } \\
(\%)\end{array}$ & $\begin{array}{c}\text { Disagree } \\
(\%)\end{array}$ & $\begin{array}{c}\text { Neutral } \\
(\%)\end{array}$ & $\begin{array}{c}\text { Agree } \\
\text { (\%) }\end{array}$ & $\begin{array}{c}\text { Strongly } \\
\text { Agree } \\
(\%) \\
\end{array}$ & Paragraph & No. \\
\hline Large & 1.08 & 3.75 & 0 & 21.3 & 9.3 & 42.7 & 26.7 & $\begin{array}{l}\text { The previous } \\
\text { meeting } \\
\text { minutes are } \\
\text { authenticated }\end{array}$ & 9 \\
\hline Large & 0.69 & 3.89 & 0 & 4 & 17.3 & 64 & 14.7 & $\begin{array}{l}\text { The meeting } \\
\text { shall be } \\
\text { opened on } \\
\text { time. }\end{array}$ & 10 \\
\hline Large & 0.92 & 4.01 & 4 & 4 & 5.3 & 60 & 26.7 & $\begin{array}{l}\text { Gathered for } \\
\text { expressing } \\
\text { their views } \\
\text { freely. }\end{array}$ & 11 \\
\hline Large & 1.31 & 3.68 & 8 & 17.3 & 5.3 & 37.3 & 32 & $\begin{array}{l}\text { Members' } \\
\text { opinion } \\
\text { respected. }\end{array}$ & 12 \\
\hline Large & 1.21 & 3.92 & 8 & 8 & 4 & 44 & 36 & $\begin{array}{l}\text { Members } \\
\text { participate in } \\
\text { decision- } \\
\text { making. }\end{array}$ & 13 \\
\hline Large & 0.94 & 4.17 & 4 & 4 & 0 & 54.7 & 37.3 & $\begin{array}{l}\text { The } \\
\text { chairperson } \\
\text { shall use his } \\
\text { powers to } \\
\text { organize the } \\
\text { meeting. }\end{array}$ & 14 \\
\hline Medium & 1.01 & 3.12 & 8 & 13.3 & 45.3 & 25.3 & 8 & $\begin{array}{l}\text { Delegations } \\
\text { are delegated } \\
\text { to members. }\end{array}$ & 15 \\
\hline Medium & 1.11 & 3.35 & 8 & 17.3 & 13.3 & 53.3 & 8 & $\begin{array}{l}\text { Decisions } \\
\text { shall be taken } \\
\text { after } \\
\text { consultation } \\
\text { with the } \\
\text { experts at the } \\
\text { meeting. }\end{array}$ & 16 \\
\hline Large & 1.04 & 3.87 & 0 & 17.3 & 9.3 & 42.7 & 30.7 & $\begin{array}{l}\text { The study fees } \\
\text { are distributed } \\
\text { during the } \\
\text { meeting. }\end{array}$ & 17 \\
\hline Large & 0.77 & 4.12 & 0 & 8 & 0 & 64 & 28 & $\begin{array}{l}\text { Meeting } \\
\text { topics are } \\
\text { displayed } \\
\text { sequentially. }\end{array}$ & 18 \\
\hline Large & 1.13 & 3.48 & 8 & 13.3 & 14.7 & 50.7 & 13.3 & $\begin{array}{l}\text { Meeting time } \\
\text { is managed } \\
\text { effectively } \\
\text { and } \\
\text { efficiently. }\end{array}$ & 19 \\
\hline Large & 0.65 & 4.11 & 0 & 4 & 4 & 69.3 & 22.7 & $\begin{array}{l}\text { A meeting } \\
\text { record is } \\
\text { recorded } \\
\text { completely. }\end{array}$ & 20 \\
\hline Large & 0.98 & 3.72 & 4 & 12 & 5.3 & 65.3 & 13.3 & $\begin{array}{l}\text { Meeting } \\
\text { sessions are } \\
\text { fine tuned. }\end{array}$ & 21 \\
\hline Very large & 0.58 & 4.23 & 0 & 0 & 8 & 61.3 & 30.7 & $\begin{array}{l}\text { All topics in } \\
\text { the record are } \\
\text { discussed. }\end{array}$ & 22 \\
\hline
\end{tabular}




\begin{tabular}{|c|c|c|c|c|c|c|c|c|c|}
\hline \multicolumn{10}{|c|}{ Theme 1: The reality of meeting management during the meeting } \\
\hline Level & $\begin{array}{c}\text { Standard } \\
\text { Deviation }\end{array}$ & $\begin{array}{l}\text { Arithm } \\
\text { etic } \\
\text { Mean }\end{array}$ & $\begin{array}{c}\text { Strongly } \\
\text { Disagree } \\
(\%)\end{array}$ & $\begin{array}{c}\text { Disagree } \\
(\%)\end{array}$ & $\begin{array}{c}\text { Neutral } \\
(\%)\end{array}$ & $\begin{array}{c}\text { Agree } \\
(\%)\end{array}$ & $\begin{array}{c}\text { Strongly } \\
\text { Agree } \\
(\%)\end{array}$ & Paragraph & No. \\
\hline Large & 0.96 & 3.41 & 0 & 20 & 32 & 34.7 & 13.3 & $\begin{array}{l}\text { Discussions } \\
\text { remain within } \\
\text { the selected } \\
\text { topics. }\end{array}$ & 23 \\
\hline Large & 1.14 & 3.63 & 0 & 25.3 & 13.3 & 34.7 & 26.7 & $\begin{array}{l}\text { The speaker is } \\
\text { listening } \\
\text { without } \\
\text { interrupting. }\end{array}$ & 24 \\
\hline Medium & 1.01 & 3.36 & 0 & 29.3 & 14.7 & 46.7 & 9.3 & $\begin{array}{l}\text { The meeting } \\
\text { is terminated } \\
\text { at the } \\
\text { specified } \\
\text { time. }\end{array}$ & 25 \\
\hline Large & 0.97 & 3.75 & & & & Total & & & \\
\hline
\end{tabular}

Table (5) shows that the total score for all the first axis averages was 3.75 and a standard deviation of 0.97. This indicates a high degree of approval by the respondents on this aspect of (22), which states that "all the subjects in the record are discussed" at the top of the mean (4.23), with a standard deviation of (0.58) indicating a very high degree of approval. ), Which states that "the subjects of the meeting are presented sequentially" with a mean (4.12) and a standard deviation of 0.65 Approval, and in the third place came paragraph (20) "Meeting Minutes are fully registered" mean (4.11) and standard deviation (0.65) which is a large degree of approval. The results of these paragraphs demonstrate awareness of the importance of managing meetings and recording their records for reference when needed.

The final paragraph (10), which states that "the powers of the members are delegated" to the middle of the account (3.12), which is a medium approval, came before paragraph (16), which states that "decisions are taken after consulting the specialists in the meeting" (3.35), which is the medium response level in the survey, was preceded by paragraph (25), which states that "the meeting is completed on time" with a mean of 3.36, which is also moderately responsive, and the results of these paragraphs indicate the medium experience it possesses Members of the academic councils of the importance of delegation of authority and consultation of specialists, and that meetings Usually exceeds the specified time because of her frequent discussions on topics may not need a long time.

(6) Table

The attitudes of members of the study community on the first axis

\begin{tabular}{|c|c|c|c|c|c|c|c|c|c|}
\hline \multicolumn{10}{|c|}{ First axis: The reality of meeting management after the meeting (follow up } \\
\hline Level & $\begin{array}{l}\text { Standard } \\
\text { Deviation }\end{array}$ & $\begin{array}{l}\text { Arithmetic } \\
\text { Mean }\end{array}$ & $\begin{array}{c}\text { Strongly } \\
\text { Disagree } \\
(\%)\end{array}$ & $\begin{array}{c}\text { Disagree } \\
(\%)\end{array}$ & $\begin{array}{c}\text { Neutral } \\
(\%)\end{array}$ & $\begin{array}{c}\text { Agree } \\
(\%)\end{array}$ & $\begin{array}{c}\text { Strongly } \\
\text { Agree } \\
(\%)\end{array}$ & Paragraph & No. \\
\hline Large & 0.79 & 3.97 & 0 & 9.3 & 4 & 66.7 & 20 & $\begin{array}{l}\text { Decisions issued } \\
\text { are clear and } \\
\text { accurate. }\end{array}$ & 26 \\
\hline Large & 1.18 & 3.61 & 4 & 18.7 & 16 & 34.7 & 26.7 & $\begin{array}{l}\text { The minutes of } \\
\text { the meeting are } \\
\text { printed and } \\
\text { distributed to the } \\
\text { two } \\
\text { communities. }\end{array}$ & 27 \\
\hline Large & 0.99 & 3.52 & 0 & 25.3 & 8 & 56 & 10.7 & $\begin{array}{l}\text { Decisions of the } \\
\text { meeting are } \\
\text { announced. }\end{array}$ & 28 \\
\hline Large & 0.54 & 3.88 & 0 & 4 & 9.3 & 81.3 & 5.3 & $\begin{array}{l}\text { The meeting } \\
\text { shall be invested } \\
\text { to achieve its } \\
\text { objectives. }\end{array}$ & 29 \\
\hline Medium & 1.04 & 3.25 & 12 & 8 & 22.7 & 57.3 & 0 & $\begin{array}{l}\text { The } \\
\text { effectiveness of } \\
\text { member } \\
\text { activities is } \\
\text { ascertained. }\end{array}$ & 30 \\
\hline
\end{tabular}




\begin{tabular}{|c|c|c|c|c|c|c|c|c|c|}
\hline \multicolumn{10}{|c|}{ First axis: The reality of meeting management after the meeting (follow up } \\
\hline Level & $\begin{array}{c}\text { Standard } \\
\text { Deviation }\end{array}$ & $\begin{array}{c}\text { Arithmetic } \\
\text { Mean }\end{array}$ & $\begin{array}{c}\text { Strongly } \\
\text { Disagree } \\
(\%)\end{array}$ & $\begin{array}{c}\text { Disagree } \\
(\%)\end{array}$ & $\begin{array}{c}\text { Neutral } \\
(\%)\end{array}$ & $\begin{array}{c}\text { Agree } \\
\text { (\%) }\end{array}$ & $\begin{array}{c}\text { Strongly } \\
\text { Agree } \\
(\%)\end{array}$ & Paragraph & No. \\
\hline Medium & 1.00 & 3.38 & 4 & 17.3 & 21.3 & 49.3 & 8 & \begin{tabular}{l}
\multicolumn{2}{c}{ Meeting } \\
improves the \\
performance of \\
the members in \\
the development \\
of examinations.
\end{tabular} & 31 \\
\hline Weak & 0.85 & 2.11 & 25.3 & 44 & 25.3 & 5.3 & 0 & $\begin{array}{l}\text { There are } \\
\text { incentives for } \\
\text { active members. }\end{array}$ & 32 \\
\hline Medium & 1.05 & 2.85 & 12 & 26.7 & 25.3 & 36 & 0 & $\begin{array}{l}\text { Plans are being } \\
\text { made to } \\
\text { implement the } \\
\text { outcome of the } \\
\text { meetings. }\end{array}$ & 33 \\
\hline Medium & 1.23 & 2.69 & 20 & 29.3 & 17.3 & 28 & 5.3 & $\begin{array}{l}\text { The results of the } \\
\text { meeting shall be } \\
\text { sent in writing to } \\
\text { the participants. }\end{array}$ & 34 \\
\hline Medium & 0.96 & 3.25 & & & & Tota & & & \\
\hline
\end{tabular}

Table (6) shows that the overall score of all the first axis averages was 3.25 and a standard deviation of 0.96 , indicating a moderate degree of approval among the surveyors (26), which states that "decisions made are clear and accurate" at the top of the mean (3.97) and a standard deviation of (0.79) indicating a high degree of approval. 29), which states that "the meeting invests to achieve its objectives" with a mean (3.88) and with a standard deviation of (0.54) The researcher attributed these results to the degree of awareness among the members of the academic councils of the importance of decisions and the investment of meetings to achieve academic goals. In the last rank, paragraph (32), which states that "there are incentives for active members" (2.11), And the researcher attributed this result to the University administration's suspension of some academic incentives, preceded by paragraph (34), which states that "the results of the meeting will be written to participants" with a mean of 2.69, which is the middle degree of response to the surveyors, Pre-heads of departments and deans are important with The members' satisfaction with the results of the meetings.

(7)Table

The attitudes of the members of the study community on the second axis

\begin{tabular}{|c|c|c|c|c|c|c|c|c|c|}
\hline Level & $\begin{array}{l}\text { Standard } \\
\text { Deviation }\end{array}$ & $\begin{array}{l}\text { Arithmetic } \\
\text { Mean }\end{array}$ & $\begin{array}{c}\text { Strongly } \\
\text { Disagree } \\
(\%)\end{array}$ & $\begin{array}{c}\text { Disagree } \\
(\%)\end{array}$ & $\begin{array}{c}\text { Neutral } \\
(\%)\end{array}$ & $\begin{array}{c}\text { Agree } \\
(\%)\end{array}$ & $\begin{array}{l}\text { Strongly } \\
\text { Agree } \\
(\%)\end{array}$ & Paragraph & No. \\
\hline Large & 0.77 & 4.09 & 0 & 4 & 13.3 & 52 & 30.7 & $\begin{array}{l}\text { Interaction between } \\
\text { administrative and } \\
\text { academic practices }\end{array}$ & 1 \\
\hline Large & 1.12 & 3.44 & 0 & 26.7 & 25.3 & 25.3 & 22.7 & $\begin{array}{l}\text { Weak experience in } \\
\text { managing meetings }\end{array}$ & 2 \\
\hline Medium & 1.12 & 3.13 & 0 & 38.7 & 26.7 & 17.3 & 17.3 & $\begin{array}{lr}\text { Discard } & \text { decisions } \\
\text { of } & \text { academic } \\
& \text { councils }\end{array}$ & 3 \\
\hline Medium & 1.32 & 3.20 & 4 & 40 & 13.3 & 17.3 & 25.3 & $\begin{array}{l}\text { Block data and } \\
\text { information about } \\
\text { members }\end{array}$ & 4 \\
\hline Medium & 0.85 & 2.85 & 0 & 38.7 & 42.7 & 13.3 & 5.3 & \begin{tabular}{ll} 
Weak desire of \\
members & to \\
participate & in \\
\multicolumn{2}{c}{ decision-making } \\
\end{tabular} & 5 \\
\hline Large & 1.18 & 3.59 & 0 & 25.3 & 21.3 & 22.7 & 30.7 & $\begin{array}{r}\text { The uniqueness of } \\
\text { decision-making }\end{array}$ & 6 \\
\hline Medium & 1.22 & 3.29 & 4 & 29.3 & 21.3 & 24 & 21.3 & $\begin{array}{lr}\begin{array}{l}\text { Weak } \\
\text { relations }\end{array} & \begin{array}{r}\text { human } \\
\text { between } \\
\text { members }\end{array} \\
\end{array}$ & 7 \\
\hline Medium & 1.13 & 3.12 & 0 & 40 & 25.3 & 17.3 & 17.3 & $\begin{array}{l}\text { Lack of interest in } \\
\text { members' opinions }\end{array}$ & 8 \\
\hline
\end{tabular}




\begin{tabular}{|c|c|c|c|c|c|c|c|c|c|}
\hline \multicolumn{10}{|c|}{$\begin{array}{l}\text { Second axis: Constraints that limit the efficiency of the performance of the meetings of the academic councils at Naif } \\
\text { Arab University for Security Sciences from the point of view of its members }\end{array}$} \\
\hline Level & $\begin{array}{c}\text { Standard } \\
\text { Deviation }\end{array}$ & $\begin{array}{l}\text { Arithmetic } \\
\text { Mean }\end{array}$ & $\begin{array}{c}\text { Strongly } \\
\text { Disagree } \\
(\%)\end{array}$ & $\begin{array}{l}\text { Disagree } \\
(\%)\end{array}$ & $\begin{array}{c}\text { Neutral } \\
(\%)\end{array}$ & $\begin{array}{c}\text { Agree } \\
(\%)\end{array}$ & $\begin{array}{c}\text { Strongly } \\
\text { Agree } \\
(\%)\end{array}$ & Paragraph & No. \\
\hline Large & 1.20 & 3.81 & 0 & 20 & 22.7 & 13.3 & 44 & \begin{tabular}{lr}
\multicolumn{2}{l}{ Absence of material } \\
and & moral \\
incentives & for \\
& members
\end{tabular} & 9 \\
\hline Medium & 1.21 & 3.01 & 9.3 & 32 & 18.7 & 28 & 12 & $\begin{array}{rr}\begin{array}{l}\text { Do not distribute } \\
\text { meeting } \\
\text { schedules } \\
\text { in advance }\end{array} \\
\end{array}$ & 10 \\
\hline Medium & 1.24 & 3.01 & 9.3 & 33.3 & 17.3 & 26.7 & 13.3 & $\begin{array}{lr}\text { Absence } & \text { of } \\
\text { transparency } & \text { and } \\
\text { fairness } & \text { in } \\
\text { presenting } & \text { the } \\
\text { topics of the } & \text { meeting } \\
\end{array}$ & 11 \\
\hline Large & 1.15 & 3.75 & 20 & 21.3 & 22.7 & 32 & 4 & $\begin{array}{l}\text { Do not specify a } \\
\text { specific time for the } \\
\text { end of the meeting }\end{array}$ & 12 \\
\hline Medium & 1.09 & 3.36 & 0 & 29.3 & 22.7 & 30.7 & 17.3 & $\begin{array}{r}\text { Weak attention to } \\
\text { meeting } \\
\text { requirements }\end{array}$ & 13 \\
\hline Medium & 1.18 & 3.07 & 0 & 46.7 & 18.7 & 16 & 18.7 & $\begin{array}{r}\text { Poor management } \\
\text { of meetings }\end{array}$ & 14 \\
\hline Large & 1.02 & 3.52 & 0 & 21.3 & 22.7 & 38.7 & 17.3 & $\begin{array}{r}\text { Non-feedback to } \\
\text { meetings }\end{array}$ & 15 \\
\hline Medium & 1.00 & 2.91 & 4 & 38.7 & 24 & 29.3 & 4 & $\begin{array}{r}\text { Report meeting } \\
\text { time insufficient }\end{array}$ & 16 \\
\hline Medium & 0.79 & 2.87 & 0 & 38.7 & 36 & 25.3 & 0 & $\begin{array}{r}\text { The objectives of } \\
\text { the meeting are } \\
\text { unclear }\end{array}$ & 17 \\
\hline Medium & 1.13 & 3.32 & 4 & 21.3 & 32 & 24 & 18.7 & $\begin{array}{l}\text { Lack of delegation } \\
\text { of authority and } \\
\text { business }\end{array}$ & 18 \\
\hline Large & 0.99 & 3.41 & 0 & 21.3 & 30.7 & 33.3 & 14.7 & $\begin{array}{l}\text { Weak attention to } \\
\text { evaluation of } \\
\text { meetings }\end{array}$ & 19 \\
\hline Medium & 1.10 & 3.19 & 4 & 30.7 & 17.3 & 38.7 & 9.3 & $\begin{array}{lrr}\begin{array}{l}\text { Absence } \\
\text { members }\end{array} & \begin{array}{r}\text { some } \\
\text { from } \\
\text { meetings }\end{array} \\
\end{array}$ & 20 \\
\hline Medium & 0.98 & 3.36 & 12 & 24 & 28 & 36 & 12 & $\begin{array}{l}\text { Influencing the } \\
\text { views of the } \\
\text { members of the } \\
\text { meetings }\end{array}$ & 21 \\
\hline Medium & 1.08 & 3.30 & & & & Tot: & & & \\
\hline
\end{tabular}

Table (7) shows that the obstacles that limit the efficiency of the performance of the meetings of the academic councils of Naif Arab University for Security Sciences from the point of view of its members indicate that the total score for all the averages of the second axis reached 3.30 and with a standard deviation of (1.08). This indicates a moderate degree of approval among the surveyors on this axis, while paragraph (1), which provides "overlap between administrative and academic practices", was obtained at the highest mean (4.09), with a standard deviation of 0.77 A large, second paragraph (9) that states "the absence of material incentives and (3.81) and a standard deviation of (1.20) which is a great degree of approval. In the third place, paragraph (12) "no specific time for the end of the meeting" was reached with a mean of 3.75 and a standard deviation of 1.15 Approval. The researcher attributes these results to the lack of clarity of the university's instructions and regulations, the overlap of powers, and the lack of incentives that contribute to the revitalization of academics. (5), which states that "the weakness of the desire of members to participate in decision-making" in the middle of the calculation (2.85), which is the degree of moderate approval, came before paragraph 17, which states "the goals of the meeting is unclear" My score was 3.35 , which is a medium response level for the surveyors. These results are due to the high degree of awareness among Members of the importance of decisions and that agendas have the capacity to set clear meeting targets.

Second: The answer to the hypothesis of the study "There are no statistically significant differences in the opinions of the respondents on the axes of the study attributed to the variables of personal and functional study". 
(8)Table

The results (One Way Analysis Of Variance) to measure the significance of differences in the premise due to the variable of Academic Rank Attainment

\begin{tabular}{|c|c|c|c|c|c|}
\hline Sig & F & Mean Square & Df & Sum Of Squares & Source of Contrast \\
\hline \multirow{2}{*}{0.882} & \multirow{2}{*}{0.126} & 54.046 & 2 & 108.092 & Between Groups \\
\cline { 3 - 5 } & & 429.869 & 72 & 30950.575 & Within Groups \\
\cline { 3 - 5 } & & & 74 & 31058.667 & Total \\
\hline
\end{tabular}

The results indicated that there were no statistically significant differences in the respondents' opinions on the study axes due to the variables of personal and functional study (academic grade). The results in the table showed that there were no statistically significant differences between the average responses of the sample members at the level of significance The value of "P" (0.126) and the statistical significance of (0.882). This is consistent with the hypothesis, which leads us to not reject the hypothesis.

\section{(9)Table}

The results (One Way Analysis Of Variance) to measure the significance of differences in the premise due to the variable of Academic experience Attainment

\begin{tabular}{|c|c|c|c|c|c|}
\hline Sig & F & Mean Square & Df & Sum Of Squares & Source of Contrast \\
\hline \multirow{2}{*}{0.121} & \multirow{2}{*}{2.004} & 808.084 & 3 & 2424.252 & Between Groups \\
\cline { 3 - 5 } & & 403.302 & 71 & 28634.414 & Within Groups \\
\cline { 3 - 5 } & & & 74 & 31058.667 & Total \\
\hline
\end{tabular}

The results indicate that there are no statistically significant differences between the average responses of the sample members at the level of significance ( The value of "P" (2.004) and the statistical significance of (0.121), and this is consistent with the hypothesis, which leads us to not reject the hypothesis.

\section{(10)Table}

The results (One Way Analysis Of Variance) to measure the significance of differences in the premise due to the variable of Age Attainment

\begin{tabular}{|c|c|c|c|c|c|}
\hline Sig & F & Mean Square & Df & Sum Of Squares & Source of Contrast \\
\hline \multirow{2}{*}{0.104} & 2.126 & 853.489 & 3 & 2560.467 & Between Groups \\
\cline { 3 - 6 } & & 401.383 & 71 & 28498.200 & Within Groups \\
\cline { 3 - 5 } & & & 74 & 31058.667 & Total \\
\hline
\end{tabular}

The results indicate that there are no statistically significant differences between the average responses of the sample members at the level of $\alpha(\alpha)=0.05)$ towards the axes of the study due to the variable of age ", where the value of" P "(2.126) and a statistical significance of (0.104), and this is consistent with the hypothesis, which leads us not to reject the hypothesis.

Table(11)

The results (One Way Analysis Of Variance) to measure the significance of differences in the premise due to the variable of College Attainment

\begin{tabular}{|c|c|c|c|c|c|}
\hline Sig & F & Mean Square & Df & Sum Of Squares & Source of Contrast \\
\hline \multirow{2}{*}{0.600} & \multirow{2}{*}{0.735} & 314.140 & 5 & 1570.699 & Between Groups \\
\cline { 3 - 6 } & & 427.362 & 69 & 29487.968 & Within Groups \\
\cline { 3 - 6 } & & & 74 & 31058.667 & Total \\
\hline
\end{tabular}

The results indicated that there were no statistically significant differences between the average responses of the sample members at the level of $\alpha(\alpha)=0.05)$ towards the axes of the study due to the macro variable ", where the value of" P "(0.735) and a statistical significance of (0.600), and this is consistent with the hypothesis, which leads us not to reject the hypothesis.

\section{(12)Table}

The results (One Way Analysis Of Variance) to measure the significance of differences in the premise due to the variable of Meetings in which they participate Attainment

\begin{tabular}{|c|c|c|c|c|c|}
\hline Sig & F & Mean Square & Df & Sum Of Squares & Source of Contrast \\
\hline 0.000 & \multirow{2}{*}{11.003} & 3635.171 & 2 & 7270.342 & Between Groups \\
\cline { 3 - 6 } & & 330.393 & 72 & 23788.324 & Within Groups \\
\cline { 3 - 6 } & & & 74 & 31058.667 & Total \\
\hline
\end{tabular}

The results indicate that there are no statistically significant differences between the average responses of the sample members at the time of the study. The level of significance $(\alpha=0.05)$ towards the study axes is due to the variable of the meetings in which it participates. "The value of" $\mathrm{P}$ "(11.003) and statistical significance of (0.000), and this corresponds to the hypothesis, which leads us to reject the hypothesis. The resulting difference in the answer between the two categories of the three categories, and to know the source only We will conduct a posthoc test (LSD) to find out the source of the difference in the responses of the study sample according to the variable of meetings, as in the following table: 
(13)Table

L.S.D. According to the variable of meetings in which the university participates

\begin{tabular}{|c|c|c|c|}
\hline Sig & $\begin{array}{c}\text { Difference in } \\
\text { Arithmetic mean }\end{array}$ & Meetings-B & Meetings- A \\
\hline 0.320 & 7.83962 & College & \multirow[t]{2}{*}{ The section } \\
\hline 0.000 & 24.27712 & Both are together & \\
\hline 0.320 & $-7.83962-$ & The section & \multirow[t]{2}{*}{ College } \\
\hline 0.063 & 16.43750 & Both are together & \\
\hline 0.000 & $-24.27712-$ & The section & \multirow[t]{2}{*}{ Both are together } \\
\hline 0.063 & $-16.43750-$ & College & \\
\hline
\end{tabular}

Where there were statistically significant differences between the average responses of the sample members who attended the meetings of the department and the sample members who attended meetings in the college, in addition to the differences between the sample of the study who attended the meetings of the faculty and the department together and the sample members who attended the college meetings. An indication of the existence of statistically significant differences between the average of the sample responses at the level of significance ( $\alpha$ $=0.05$ ) on the "Reality of the meetings of the academic councils at Naif Arab University for Security Sciences and its obstacles".

(14)Table

Test results (T.TEST) depending on the variable "Have you got a training course in meeting management?" Attainment

\begin{tabular}{|r|r|c|c|c|c|}
\hline \multirow{2}{*}{ Sig } & \multirow{2}{*}{$(\mathbf{T})$} & \multicolumn{2}{|c|}{ NO } & \multicolumn{2}{c|}{ YES } \\
\cline { 3 - 6 } & & Standard Deviation & Arithmetic Mean & Standard Deviation & Arithmetic Mean \\
\hline $\mathbf{0 . 2 1 4}$ & $\mathbf{0 . 6 5 6}$ & $\mathbf{0 . 3 4}$ & $\mathbf{3 . 5 3}$ & $\mathbf{0 . 4 0}$ & $\mathbf{3 . 4 7}$ \\
\hline
\end{tabular}

Statistically significant at significance $(0.05)$

The hypothesis stated that "Are there statistically significant differences in the opinions of respondents on the study axes due to the variables of the personal and functional study (variable did you get a training course in the management of meetings)?" The results in the table showed that there are no statistically significant differences between the average The responses of the sample members at the level of significance $(\alpha=0.05)$ towards the study axes are due to the variable did you get a training course in the management of the meetings ", where the value of" $\mathrm{T}$ "(0.656) and a statistical significance of (0.214), and this is consistent with the hypothesis, Which leads us not to reject the hypothesis.

4. Findings: This section contains the main findings of the study that can be summarized as follows:

1. The objectives of the meeting are strictly defined, the venue and time of the meeting are determined in the invitation, and emergency meetings are called when necessary. These results were similar with the study of (Amiri 2007), and differed with the study (Al-Hawamdeh,2003).

2. Delegations are delegated to the members and decisions are made after consultation with the experts at the meeting. The meeting is concluded on time and to a medium extent of the responses of the study community.

3. Meeting topics are presented sequentially, a meeting minutes are recorded in full, and all the topics listed in the meeting minutes are discussed.

4. The decisions issued are usually clear and accurate. This result is similar to the study of (Masri 2007).

5. That the meeting invests to achieve its objectives similar to this result with the study (Ameri 2007), And disagreed with the study (Alonze, 2004), which stated that criteria must be set to achieve the goals.

6. There is a lack of incentives for active members. And that the results of the meeting do not send written to the participants, and similar result with the study (kara, 2001), and the study (Barhoum 2006).

7. The results of the study showed that the overlap between administrative and academic practices and individual decision-making, the absence of material and moral incentives for members and the lack of specific time for the end of the meeting is one of the most important difficulties facing the management of meetings.

8. There is a strong desire among members to participate in making decisions, and the objectives of the meeting are clear.

9. The results of the study indicate that "there are no statistically significant differences in the opinions of the respondents on the subject of the study due to the variables of the study" Academic Rank, Academic Experience, Age, Experience.

10. The results of the study showed that "there are statistically significant differences in the opinions of the respondents on the subjects of the study due to the variable meetings in which they participate". 
5. RECOMMENDATIONS: The researcher presented a set of recommendations that can be summarized as follows:

1. Delegation of powers to members participating in meetings.

2. Decisions must be made after consultation with the meeting specialists.

3. The need to end the meeting in a timely manner away from the waste of time.

4. Material and moral incentives should be provided to the active members of the meetings because they have a significant impact on the increased attention and activity in the implementation of the decisions of the meetings.

5. The results of the written meeting should be sent to the participants to follow up and fulfill the objectives of the meetings.

6. Management and academic practices should be separated during meetings, non-singular decision-making and specific time for the end of the meeting.

7. The need to increase the experience of those responsible for the management of meetings through appropriate training courses.

8. Meetings management should send the necessary information and data about the meetings to the members as a feedback for the benefit and follow-up of the meeting activities.

9. The importance of evaluating meetings from time to time to correct deviations in decision-making, if any.

\section{REFERENCES}

1. Al-Hajili, Nasr (2010): The views of the heads of academic departments at the University of Dhamar towards their administrative and academic duties, Damascus University Journal, vol. 26.

2. Al-Hawamdeh, Nidal (2003): The Relationship of the Elements of the Management of Meetings to their Efficiency and Effectiveness in the Jordanian Ministries, A Field Study, Administrative Sciences Studies, vol 30, no. 1.

3. Al-Houli, Alian (2005): The Academic Department of the University, Concept and Role, Journal of Quality in Higher Education, Islamic University, Vol 1, No.2, Gaza.

4. Al-Muneef, Ibrahim (2004): Position of the Director General, Dar Al-Raya Al Sharqiya for Publishing and Distribution, Riyadh.

5. Alonozo, Vincent. (2004): "Evaluating Your Meeting". Successful Meetings, Vol. 53, No. 6: 33.

6. Al-Sakarna, Bilal (2009): Management Skills in Self Development, Dar Al-Masirah for Publishing, Distribution and Printing.

7. Amiri, Ahmed (2007): Effectiveness of the management of meetings in the councils of the academic departments at King Saud University, a controlled search.

8. Ann, Boehme (2010): Planning Successful Meetings And Events Amaccom, New York, USA.

9. Barhoum, Ahmed (2006): The reality of managing the meetings of the academic departments in Palestinian universities from the perspective of faculty members and ways of activating them, Master Thesis, Gaza.

10. Dijani, Iyad (2011). The role of strategic planning in the quality of institutional performance, descriptive descriptive study in Palestinian regular universities, unpublished doctoral thesis, Damascus University, Faculty of Education, Syria.

11. Gary, Cohen (2012): Jus Ask Leadership: Why Great Managers Always Ask The Right Questions, Mc GrawHill Co, USA.

12. Harbi, Mohamed (2001): University Administration, II, Dar Al Yazouri Scientific Publishing and Distribution, Amman.

13. Kara, Kuryllowicz. (2001): "How To Run An Effective Meeting". Profit Periodical, Vol. 20, No. $3: 9$.

14. Lynne, Gaines, Ets (2011): Planning And Running A Successful Meeting, Boston College, USA.

15. Maher, Ahmed (2000): How to increase your administrative skills in communication, university house, Alexandria.

16. Malhotra, Narsh,(2007): Marketing Research, Pearson Education, Prentice-Hall Inc. New Jersey.

17. Marlene, Rebori,(2010): How to Organize and Run Effective Meeting, University of Nevada, USA.

18. Masri, Marwan (2007): Development of the administrative performance of the heads of academic departments in Palestinian universities in light of the principles of total quality, Master Thesis, Islamic University, Gaza.

19. Messmer, Max. (2002): "Conducting Effective Meetings". National Public Accountant.

20. Sadeh, Jawdat (2003): Development of the administrative and leadership role of the head of the academic department at An-Najah National University, presented to the University of An-Najah History and Development Conference, held on 18-6-2003.

21. Sharon, Anderson (2012): How To Run A Meeting, Oregon, University, Portland, USA.

22. Shuaib, Abdulrahman (2004): Evaluation of teaching staff members at the University of Aden for meetings held in their colleges, Master Thesis, Yemen. 